\title{
Attitudes of Jordanian EFL Students towards Learning English Idioms
}

\author{
Sana' Ababneh \\ Al-Balqa'a Applied University, Huson University College, Huson, Jordan \\ E-mail: sanabneh@yahoo.com
}

Received: February 29, 2016 Accepted: March 11, 2016 Published: March 12, 2016

doi:10.5296/ijele.v4i1.9171 URL: http://dx.doi.org/10.5296/ijele.v4i1.9171

\begin{abstract}
This paper presents the results of a field study which was carried out to identify Jordanian EFL students' attitudes towards learning English idioms. The study sample consisted of 94 students majoring in Translation and English Language and Literature at Yarmouk University, Jordan. A questionnaire was used to investigate the subjects' attitudes. The findings show that the majority of the participants have positive attitudes towards learning English idioms as they believe in their importance for achieving effective communication in English. Moreover, the data show that neither the subjects' gender nor their academic major has a significant effect on their attitudes towards learning English idioms as most of the participants displayed a highly positive attitude towards learning these idioms.
\end{abstract}

Keywords: English idioms, attitudes, gender, Jordanian EFL learners 


\section{Introduction}

Vocabulary, being "the building blocks of language", to use Brown's (2001, p. 377) words, deserves, according to him, to be allocated specific class time since its learning is a priority if one desires to create productive communicative learners. Vocabulary teaching has witnessed a great shift from teaching lists of separate words to teaching chunks of language, which is believed to be more natural and more beneficial in learning language. Learning such fixed expressions or chunks as idioms, collocations, phrasal verbs and proverbs reflects a mastery of the target language and using them in talking is more natural and appropriate, which should facilitate effective communication.

Paying special attention to idioms in an EFL classroom is especially significant if one considers the opaque, figurative nature of idioms whose overall meaning as units is different from the sum of the meanings of their forming constituents (Cf. Richards, Platt \& Platt [1992, p. 172] who define an idiom as "an expression which functions as a single unit and whose meaning cannot be worked out from its separate parts".) This is what makes this component of vocabulary problematic to foreign learners. Someone who knows the meaning of the separate parts but has not yet met the whole chunk as a unit is not expected to understand and to use the idiom. Therefore, exposing the learner to the whole chunk, i.e., the idiom, as a unit is indispensible if he or she is to learn it effectively and usefully. Thus learning idioms as whole chunks becomes essential for a foreign language learners aiming for a good mastery of the target language to help them communicate in the language more effectively. This is especially true in light of the fact that idioms incorporate cultural aspects (Bachman, 1990) whose knowledge is vital to the foreign learner since mastery of a language is incomplete without a good understanding of the culture of that language.

The benefits of teaching and learning idioms have been addressed by Detry (quoted in Cuadros, 2014, p. 19) who points out four aspects of learning that are fostered by the introduction of idioms instruction in the FL curriculum: the communicative, cultural, metaphorical-cognitive and psycho-affective aspects. Therefore including idioms as part of the vocabulary instruction of the target language can surely help learners in enhancing their understanding and their use of the language. Add to this what Cuadros (2014, p. 20) mentions when he claims that leading students to the study and acquisition of idioms means fostering and developing their intercultural communicative competence in the target language. In other words, it not only the purely linguistic import of idioms that counts but idioms are also an important aid to the study of the culture whose understanding is crucial to the learning of a foreign language.

To turn to attitudes, these have recently received attention in the field of acquiring either first or second/foreign language. Gardner (1985, pp.91-93) asserts that an attitude is an evaluative reaction to some referent inferred on the basis of the individual's beliefs or opinion about the referent. Researchers in this regard believe that student's attitude is an integral part of the general process of learning and that it should, therefore, become a significant part in learning a second/ foreign language as well (Ababneh, 2012, p. 46). Moreover, learning occurs more easily, when the learner has a positive attitude towards the target language and towards 
learning in general (Chamber, 1999). This is in agreement with Gardner and Lambert (1972) who prove that positive attitudes towards language surely enhance learners' proficiency in that language.

\section{Related Studies}

Since learning idiomatic expressions of the target language plays an important part in acquiring that language, many studies have been conducted to investigate this area of language learning. For example, Tadayyon and Ketabi (2014) have conducted a study on Iranian EFL learners' attitudes towards learning English idioms. Their work proves that Iranian EFL learners have a positive attitude towards learning English in general as well as towards learning idioms in particular. In the same vein, Gahroei and Tabatabaei (2013) investigate the attitudes of Iranian EFL learners towards learning English idioms and examine the effect of using two different methods in teaching idioms. One incorporates teaching idioms through their etymologies and movie clips, while the other incorporates using the traditional methods of teaching. Findings of their study reveal that participants who are exposed to the idioms in etymology and movie clips have better performance and positive attitudes towards learning idioms than their colleagues in the other group.

Khan and Daşkin (2014) emphasize the fact that since idioms have cultural and figurative aspects, they cannot be easily comprehended and used appropriately, unless they are taught explicitly by means of special instructional materials in language classrooms. In addition, they tried to study Turkish EFL teacher-trainees' attitudes towards idioms, their use and perceptions of idioms and idiom instruction. Their findings show that the Turkish teacher-trainees hardly use idioms in their materials and those who use them usually do not incorporate them in a way to help enhance learners' communicative competence. This has led them to conclude that the teacher-trainees' insufficient idiom learning experience in the past could have been influential in their use of idioms in the materials, although they did show positive attitudes towards idiom instruction.

Tran (2013) explores the figurative idiomatic competence of language learners and their perceptions of idiom learning in an EFL context in Vietnam. His findings show that the students have poor idiomatic competence. His efforts have also uncovered the paradox between the students' situation of using and learning idioms and their desires to learn. He claims that figurative idioms should be inclusively taught with the skills of negotiation of meaning. Moreover, learners should be exposed to a variety of idioms which are not exclusively from traditional English-speaking countries but also from the countries of the outer- and expanding-circle contexts.

Chuang (2013) investigates the relationship between EFL learners' vocabulary size in L2 and their competence in reading comprehension with idioms. Her study proves that learners' vocabulary size and their idiom proficiency, as well as their ability in reading comprehension are all positively related. Thus developing EFL learners' idiomatic knowledge is essential in enabling the learners to use the language appropriately. This is also supported by the findings 
of Tran (2012) who implies that idiom learning should receive more attention in EFL learning context.

\section{Significance of the Study}

In the case of vocabulary teaching, idioms are seen as frequently used expressions that contain cultural aspects and are, therefore, ways of comprehending the culture of the target language. They are also very rich in terms of meaning (cf. Bachman, 1990). Their importance as aspects of the vocabulary earns them a high priority in the EFL classroom. Nevertheless, due to their figurative nature, students usually have problems understanding and acquiring them. Their importance and their special acquisition difficulties are enough reason for introducing them and giving them special attention in teaching a foreign language. The present study attempts to shed light on the attitudes that Jordanian EFL students have towards learning English idioms and to examine the influence that gender and academic major has on these attitudes since learning idioms could foster students' proficiency and fluency in English. This is especially useful due to the close interdependence between learners' attitudes and the ease with which these idioms can be learned. A better understanding of students' attitudes may assist EFL teachers and curriculum and instructional materials' designers to provide language teaching materials that suit the desires and attitudes of the learners.

\section{Questions of the Study}

The present study attempts to shed light on the attitudes of Jordanian EFL students towards learning English idioms. To achieve the set goals of the study, it will attempt to answer the following questions:

1. What are Jordanian EFL students' attitudes towards learning English idioms?

2. Are there any significant differences among students' in the question of idioms and their learning that could be attributed to the differences in their gender?

3. Are there any significant differences among students' in this regard that could be attributed to the differences in their academic major?

\section{Methodology}

To achieve the goals of the study, the researcher adopted a questionnaire from Khan \& Daşkin( 2014, p.114) as a research tool. The questionnaire consisted of a number of statements for the respondents to indicate the degree of their agreement or disagreement with their content.

\subsection{Participants}

The participants in this study were students in two different departments at Yarmouk 


\section{Macrothink}

University: the Department of Translation and the Department of English Language and Literature. They were registered in two introductory courses (one in semantics and the other in phonology) at the Department of English Language and Literature during the first semester of the academic year 2015/2016. The total number of the subjects was 94: twenty-one female students and 73 male students. The English Language and Literature students were 23 while the subjects from the Translation Department were 71. (See Table 1). All the students in the two sections filled the questionnaire which was originally designed to identify attitudes towards learning English idioms.

Table 1. Numbers and Percentages of the Participants of the Study

\begin{tabular}{|l|c|c|}
\hline Participants' Gender/Major & Number & Percentage \\
\hline Male & 73 & 77.7 \\
\hline Female & 21 & 22.3 \\
\hline Total & $\mathbf{9 4}$ & $\mathbf{1 0 0 . 0}$ \\
\hline \hline English Language and Literature & 23 & 24.5 \\
\hline Translation & 71 & 75.5 \\
\hline Total & $\mathbf{9 4}$ & $\mathbf{1 0 0 . 0}$ \\
\hline
\end{tabular}

\subsection{Instrument of the Study}

The main instrument of this study was a questionnaire adopted from Khan \& Daşkin ( 2014, p.114) which consisted of 20 statements. The subjects were asked to indicate their agreement with these statements or lack thereof by choosing one of three alternatives: (strongly) disagree, neutral, or (strongly) agree. The researcher aimed to identify the subjects' attitudes, as well as to examine the differences between these attitudes that could be attributed to the difference in gender, or academic major.

All the statements of the questionnaire were written in English and the students ticked the appropriate response in the presence of the researcher and their instructor who answered any inquiries that the respondents had about those statements.

\subsection{Data Collection}

This study was carried out at Yarmouk University. Permission was sought from the professor who taught the two courses and who also helped administer the questionnaire. Prior to distributing the questionnaire, the subjects were informed of the objectives and the significance of the study. They were also told that their responses would remain confidential. They were requested to state their true and honest responses. Moreover, they were able to ask for any clarification they might need.

\subsection{Data Analysis Procedures}

The present study basically sought to identify Jordanian EFL students' attitudes towards learning English idioms. The data collected from their responses to the questionnaire statements was analyzed as follows: a response of (strongly) agree was considered positive 
and was awarded three points; neutral, two points; and (strongly) disagree, a negative response, one point. Mean scores and standard deviations were computed using the Statistical Package for Social Sciences (SPSS). The results are shown in Table 2 with mean scores and standard deviations (SD's) arranged in descending order.

\section{Limitations of the Study}

Generalizing the findings of this study unfortunately suffers from the following limitations: First, the study is limited to Jordanian EFL students registered in two introductory courses (one in semantics and the other in phonology) at the Department of English Language and Literature. Choosing more courses and more than one institution could have provided more reliable data. Secondly, it suffers from the small size of the sample, i.e., the small number of subjects. A larger sample would have been more representative and more reliable.

\section{Findings and Discussion}

The first question the present study sought to answer was What are Jordanian EFL students' attitudes towards learning English idioms? The analysis of the data was based on the students' responses to the twenty statements of the questionnaire described above.

Table 2. Results concerning students' attitudes towards learning English idioms

\begin{tabular}{|c|l|c|c|}
\hline No. & \multicolumn{1}{|c|}{ Questionnaire Item } & $\begin{array}{c}\text { Mean } \\
\text { Scores }\end{array}$ & $\begin{array}{c}\text { Standard } \\
\text { Deviation }\end{array}$ \\
\hline 1 & $\begin{array}{c}\text { I think it is important to encourage English language } \\
\text { learners to learn idioms for effective communication. }\end{array}$ & 2.80 & 0.56 \\
\hline 2 & $\begin{array}{l}\text { I believe learning English idioms is an important part of } \\
\text { English language learning experience. }\end{array}$ & 2.77 & 0.52 \\
\hline 3 & $\begin{array}{l}\text { Learning to use English idioms is necessary for achieving } \\
\text { effective communication. }\end{array}$ & 2.71 & 0.54 \\
\hline 4 & $\begin{array}{l}\text { Learning to use English idioms in oral communication is } \\
\text { necessary for developing my speaking skills. }\end{array}$ & 2.71 & 0.54 \\
\hline 5 & $\begin{array}{l}\text { Knowing English idioms is necessary for me to understand } \\
\text { the everyday language better. }\end{array}$ & 2.67 & 0.61 \\
\hline 6 & $\begin{array}{l}\text { Knowing English idioms is important for me to understand } \\
\text { the target culture better. }\end{array}$ & 2.64 & 0.64 \\
\hline 7 & $\begin{array}{l}\text { Learning English idioms is important for me to get familiar } \\
\text { with the English figurative expressions. }\end{array}$ & 2.64 & 0.65 \\
\hline 8 & $\begin{array}{l}\text { Learning English idioms is important for me to develop my } \\
\text { skill of expressing myself by using figurative language in } \\
\text { English. }\end{array}$ & 2.64 & 0.65 \\
\hline 9 & $\begin{array}{l}\text { Knowing English idioms is important for me to comprehend } \\
\text { the listening texts better }\end{array}$ & 2.63 & 0.57 \\
\hline
\end{tabular}




\begin{tabular}{|c|l|c|c|}
\hline 10 & $\begin{array}{l}\text { I will definitely teach English idioms when I become an } \\
\text { English teacher. }\end{array}$ & 2.62 & 0.62 \\
\hline 11 & $\begin{array}{l}\text { We might need to recognize and understand English idioms } \\
\text { when we have to communicate in English outside the } \\
\text { classroom. }\end{array}$ & 2.60 & 0.68 \\
\hline 12 & $\begin{array}{l}\text { I believe it is necessary to incorporate English idioms in } \\
\text { English course books }\end{array}$ & 2.60 & 0.68 \\
\hline 13 & $\begin{array}{l}\text { I think English idioms should be a part of the English } \\
\text { language curriculum at schools. }\end{array}$ & 2.57 & 0.61 \\
\hline 14 & $\begin{array}{l}\text { I think it is important to teach English idioms in English } \\
\text { classrooms. }\end{array}$ & 2.56 & 0.66 \\
\hline 15 & $\begin{array}{l}\text { Knowing English idioms is important for me to comprehend } \\
\text { the reading texts better. }\end{array}$ & 2.55 & 0.65 \\
\hline 16 & $\begin{array}{l}\text { Using idioms when I give oral presentations in English will } \\
\text { make my speech more effective. }\end{array}$ & 2.53 & 0.68 \\
\hline 17 & $\begin{array}{l}\text { Knowing English idioms is important for me to perceive the } \\
\text { cultural differences and similarities better }\end{array}$ & 2.53 & 0.68 \\
\hline 18 & $\begin{array}{l}\text { We might need to use English idioms when we have to } \\
\text { communicate in English outside the classroom }\end{array}$ & 2.53 & 0.70 \\
\hline 19 & $\begin{array}{l}\text { Knowing English idioms is necessary for me to make sense } \\
\text { of the humors generated in English. }\end{array}$ & 2.45 & 0.65 \\
\hline 20 & $\begin{array}{l}\text { Learning to use English idioms in written communication is } \\
\text { necessary for developing my writing skills. }\end{array}$ & 2.27 & 0.71 \\
\hline & \multicolumn{1}{|c|}{ Total } & 0.35 \\
\hline
\end{tabular}

Table 2 shows the mean scores and the standard deviations of students' responses on each questionnaire statement that cater for determining their attitudes towards learning English idioms. The numbers in Table 2 indicate that the students' mean scores range between 2.27 and 2.80. The highest mean goes to the statement I think it is important to encourage English language learners to learn idioms for effective communication, and the lowest to Learning to use English idioms in written communication is necessary for developing my writing skills. The overall mean score for the subjects' responses was 2.60. A $t$-test was used to see whether the subjects have positive or negative attitudes towards learning English idioms. Results obtained from this test prove that students have positive attitudes towards learning English idioms since the $t$ value was (16.541), a positive and statistically significant value at $(\alpha \leq 0.05)$. $\mathrm{S}$ Results of t-test of students' attitudes towards learning English idioms ee Table 3.

Table 3.

\begin{tabular}{|lll|l|l|c|l|l|}
\hline & & Mean & SD & Importance & T & Sig. \\
\hline $\begin{array}{l}\text { EFL students' attitudes towards learning } \\
\text { English idioms. }\end{array}$ & 2.60 & 0.35 & high & 16.541 & 0.00 \\
\hline
\end{tabular}




\section{Macrothink}

The second question the study sought to answer was whether there are any significant differences among students' responses to the questionnaire statements due to the differences in gender. To see if there are significant differences between students' responses on the questionnaire items at $(\alpha \leq 0.05)$ that could be attributed to their gender, the researcher did a $t$-test for equality to the mean scores of the students' responses according to their gender. Table 4 shows the results.

Table 4. Mean scores and t-test of respondents' attitudes towards learning English idioms according to their gender

\begin{tabular}{|c|l|c|c|c|}
\hline Gender & Mean & Std. Deviation & $\mathrm{T}$ & Sig. \\
\hline Male & 2.58 & 0.43 & 0.28 & 0.78 \\
\hline Female & 2.61 & 0.32 & & \\
\hline
\end{tabular}

Results obtained from Table (4) show that the $t$ value was (0.28). This indicates that there are no significant differences between the respondents' responses to the questionnaire statements that could be due to gender.

The third question of this study aimed at investigating the effect of the academic major (Translation vs. English Language and Literature) on the respondents' attitudes towards using English idioms. To achieve this goal, the researcher did a $t$-test of equality between the mean scores of the respondents according to their academic major. Table 5 presents this.

Table 5. Mean scores and t-test of respondents' attitudes towards learning English idioms according to their academic major.

\begin{tabular}{|c|c|c|c|c|}
\hline Major & Mean score & Std. Deviation & $\mathrm{T}$ & Sig. \\
\hline Translation & 2.61 & 0.33 & 0.58 & 0.56 \\
\cline { 1 - 4 } English Language and Literature & 2.56 & 0.42 & & \\
\hline
\end{tabular}

The data presented in Table 5 show that the $t$ value was $(0.58)$. This indicates that there are no significant differences between the subjects' attitudes that could be attributed to the difference in their academic major.

\section{Conclusion and Recommendations}

A number of conclusions could be drawn from the findings of this study. First, in agreement with the findings an earlier study (Ababneh 2012, p.51), the present study showed that Jordanian EFL students have positive attitudes towards learning English idioms. Their overall mean score was (2.60) out of (3.00); a mean score of (3.00) means strong agreement by all participants on all items; (2.60) is not very far from this.

These positive attitudes indicate that students like to have a native-like mastery of the English 
language. This mastery is defective without satisfactory familiarity with idioms since the use of these idioms constitutes a mark of competence in the target language.

Moreover, gender seems to have no significant effect on the subjects' attitudes toward learning English idioms. Male students' mean score was (2.58), female students (2.61). Both male and female students have strong motivation to acquire the language properly, idioms being a good indicator of the success of this endeavor. This only goes to prove how important English is to the whole society.

When it comes to the academic university major, again there seems to be no significant effect. Translation majors' mean score was (2.61) compared to English Language and Literature majors' mean score of (2.56). It is clear that the mean scores are very similar; both majors are highly motivated and display a positive attitude towards learning English idioms.

Based on these conclusions and the literature in the field, a number of recommendations could made. Learners' positive attitudes towards learning English idioms should be taken advantage of by EFL teachers and curriculum designers: idioms should take the share they deserve of educationists' planning efforts and practice (Cf. Khan and Daşkin [2014, p.97] who emphasize the role of culture-specific expressions in developing future teachers' language, as well as pedagogic competence).

In this endeavor, it should be clear to teachers, and made clear to learners, how important the mastery of idioms is and how their use enables the learner to produce native-like language since much of everyday language includes idioms. In addition, idioms contain cultural aspects and ways of perceiving reality of the target language community whose knowledge is indispensible for a mastery of the foreign language.

This kind of emphasis is especially needed in the light of the opaqueness of the meaning of idioms whose overall meaning is different from the sum of the meanings of their constituent parts, which usually constitutes a serious difficulty for the learner of a foreign language (cf. Cuadros, 2014, p.6). Students' awareness of the importance of idioms in developing their fluency in the target language and the special figurative nature of these idioms and their opaqueness should be raised. Special exercises and explanatory notes should be of paramount importance in the EFL classes to help learn idioms and counter the difficulty of their interpretation..

In short, for EFL learners' proficiency in English to be satisfactory, idioms must be part of this proficiency. EFL teachers should be encouraged to empower their students to acquire those aspects of the foreign language they are targeting which constitute an indispensible component of the structure of the language. Without sufficient knowledge of these idioms, students' competence remains lacking in an important aspect of the language.

\section{References}

Ababneh, S. (2012). Motivation and attitudes of vocational education female students towards learning English. International Journal of Vocational Education and Training, 20, 
43-52.

Bachman, L. F. (1990). Fundamental considerations in language testing. Oxford: OUP.

Brown, H. D. (2001). Teaching by principles: An interactive approach to language pedagogy (2nd ed.) White Plains, NY: Longman.

Chamber, G. N. (1999). Motivating language learners. Clevedon: Multilingual Matters. Ltd.

Chuang, Y. (2013). A Study of the Relationship between College EFL Learners' Vocabulary Size and Idiomatic Reading Comprehension. NCUE Journal of Humanities, 7, 59-76.

Cuadros, M. G. (2014). A Study on the Effectiveness of Metaphor and Cultural Awareness-Raising to the Learning of Idioms in the EFL Classroom. Unpublished M.A. thesis, Spain.

Gahroei, F. R., \& Tabatabaei, O. (2013). Impact of L2 Film Instruction and English Idiom Etymology on Iranian EFL Learners' Idiom Learning. Iranian Journal of Research in English Language Teaching, 1(1), 45-61.

Gardner, R., \& Lambert, W. (1972). Attitudes and motivations in second language learning. Rowley, Massachusetts: Newbury House Publishers.

Gardner, R. (1985). Social psychology and second language learning: The role of attitude and motivation. London: Edward Arnold.

Khan,Ö., \& Daşkin N. C. (2014). You Reap What You Sow” Idioms in Materials Designed by EFL Teacher-Trainees. Novitas-ROYAL (Research on Youth and Language), 8(2), 97-118.

Richards, J. C. Platt, J., \& Platt, H. (1992). Language teaching and applied linguistics. London: Longman.

Tadayyon, M., \& Ketabi, S. (2014). Iranian EFL Learners' Attitude towards Idioms in English. Theory and Practice in Language Studies, 4(3), 608-612.

Tran, H. Q. (2013). Figurative Idiomatic Competence: An Analysis of EFL Learners in Vietnam. Language Education in Asia, 4(1), 23-38.

Tran, H. Q. (2012). An Explorative Study of Idiom Teaching for Pre-service Teachers of English. English Language Teaching, 5(12), 76-85.

\section{Copyright Disclaimer}

Copyright for this article is retained by the author(s), with first publication rights granted to the journal.

This is an open-access article distributed under the terms and conditions of the Creative Commons Attribution license (http://creativecommons.org/licenses/by/3.0/). 